\title{
Results Concerning the Influence of Fruit Load Upon Plum Fruit Quality
}

\author{
Flavia Andreea TRIPON ${ }^{1 *}$, Viorel MITRE ${ }^{1)}$, Ioana MITRE ${ }^{1)}$, Dorin BADIU ${ }^{1)}$, \\ Monica PAL ${ }^{1)}$, Mihai LAZAR ${ }^{1)}$ \\ ${ }^{1)}$ Department of fruit growing, University of Agricultural Sciences and Veterinary Medicine, \\ Cluj-Napoca, Romania \\ ${ }^{*}$ Corresponding author, e-mail: andreeaflavia_tripon@yahoo.com
}

Bulletin UASVM Horticulture 71(2) / 2014

Print ISSN 1843-5254, Electronic ISSN 1843-5394

DOI:10.15835/buasvmcn-hort:10637

\begin{abstract}
Chemical thinning consists in spraying the trees with different substances. The intensity of chemical thinning depends on the vigour of the tree, the phenophase in which it is done, the type of solution and its concentration. In this study for the chemical thinning the following products were used: Ethrel, $0.01 \%$ in concentration, Cosavet 80 DF, in concentration of 5\%, Sulphur 80 WG, in concentration of $5 \%$ and Sulfomat 80 PU, in concentration of $5 \%$, when $80 \%$ of the flowers were open. The study took place in fruit-growing ecosystems Călacea and Steluța, by analyzing 7 varieties of plum, in the following order: 'Tuleu timpuriu', 'Stanley', 'Gras Ameliorat', 'Anna Spath', 'Tuleu gras', 'Vinete Românești', 'Vinete de Italia' and 'Nectarină roșie'. On these varieties were conducted determinations regarding thinning influence on: dry substance and total acidity. In Călacea fruitgrowing ecosystem, regardless the treatment, the highest dry substance content was obtained by 'Stanley' variety (15.57\%), and in Agroindustriala ecosystem, the highest value for dry substance content was registered by ,Vinete de Italia' variety (20.19\%). The results show that regardless the treatment, in Călacea fruit-growing ecosystem the highest value for acidity was obtained by ,Tuleu Timpuriu' variety (10.9540 \%), and in Agroindustriala fruitgrowing ecosystem the highest acidity was registered by ,Tuleu Gras' variety (12.88 \%).
\end{abstract}

Keywords: acidity, sugar, thinning, quality, quantity

Introduction. Thinning intensity depends on various factors: species, variety, tree vigour, the period when the treatment is applied, the solution type, concentration, the applied dose and the administration mode (Venig, 2006). Thinning is used with the purpose of obtaining high quality fruits. (Dagar et al, 2012; Stern et al. 2009; Wertheim, 2000).

Aims and objectives. The study has been conducted with the porpuse of determining the influence of fruit load upon fruit quality on 7 plum varieties.

Materials and methods. For the chemical thinning, the following products were used: Ethrel $0.01 \%$ in concentration, Cosavet 80 DF in concentration of $5 \%$, Sulphur 80 WG in concentration of $5 \%$ and Sulfomat $80 \mathrm{PU}$, in concentration of $5 \%$, when $80 \%$ of the flowers were open. On these varieties were made determi- nations regarding thinning influence on: dry substance (\% SU) and total acidity (\% malic acid). Dry substance content was determined using the refractometer, model ML-BOE 32195. For this analysis it was used fresh juice from fruits at consumption ripeness moment. Sugar content was obtained by determining the dry substance (\%) and through deriving the result. The following formula was used: $\mathrm{Z}(\%)=\left[\left(\mathrm{n}^{*} 4,25\right) / 4\right]-2,5$; where $\mathrm{n}$ represents the value read on the dial, corresponding to dry substance. Fruits acidity was expressed in malic acid, and the following formula was used: $\mathrm{A}_{\%}=\left(n \times f \times k \times v_{1}\right) /\left(g \times v_{2}\right)$ $x$ 100; where $n$ represents $\mathrm{ml} \mathrm{NaOH} \mathrm{n} / 10$ which was titered, f represents factor solution of $\mathrm{NaOH}$ $\mathrm{n} / 10$, k represents the acid that express the result of determination ( that corresponds to $1 \mathrm{ml}$ of $\mathrm{NaOH} n / 10$ ), $\mathrm{v}^{1}$ represents the volume of extract ( graduated cylinder or volumetric flask), the result 
before filtration ( $100 \mathrm{ml}$ in this case), g represents the sample weight from wich was obtained the

extract, in $\mathrm{g}$ (10 g in this case ), $\mathrm{v}^{2}$ represents the volume of filtrate that was analyzed, in $\mathrm{ml}(25 \mathrm{ml}$ in this case) and A represents total titrable acidicy ( $\%$ predominantly acid).

Results and Discussion. Regarding dry substance content (\%), two factors have a very significant influence, beginning with the variety ( $\mathrm{F}$ $=107.474, \mathrm{p}<0.000$ ), and the applied treatment $(F=6.916, p<0.000)$. It can be seen that in Călacea fruit-growing ecosystem, regardless the treatment, the highest dry substance content was obtained by 'Stanley' variety (15.57\%), followed by ,Anna Spath' variety (14.34\%), ,Gras Ameliorat' (14.14 \%) and ,Tuleu Timpuriu' variety (11.38 \%). In Agroindustriala ecosystem, regardless the treatment, the highest value for dry substance content was registered by ,Vinete de Italia' variety (20.19\%), followed by ,Vinete Românești' variety (17.94 \%), ,Nectarină Roșie' variety (17.45 \%), ,Tuleu Gras' (17.23\%) and ,Stanley' variety (15.07 $\%)$. Concerning total acidity (\% malic acid), the two factors together with their interaction have a very significant influence, beginning with the variety $(\mathrm{F}=3841.623, \mathrm{p}<0.000)$, variety $\mathrm{x}$ treatment interaction $(\mathrm{F}=53.701, \mathrm{p}<0.000)$ and the applied treatment $(\mathrm{F}=7.011, \mathrm{p}<0.000)$. The results show that regardless the treatment, in Călacea fruit-growing ecosystem the highest value for acidity (\% malic acid) was obtained by
,Tuleu Timpuriu' variety (10.9540\%), after which followed ,Stanley' variety (4.4060 \%), ,Anna Spath' (3.8660 \%) and ,Gras Ameliorat' variety (3.6987 $\%)$. In Agroindustriala fruit-growing ecosystem the highest acidity (\% malic acid) was registered by ,Tuleu Gras' variety (12.88\%), followed by „Nectarină Roșie' variety (8.13\%), ,Vinete de Italia' (7.46 \%), ,Vinete Românești' (5.95 \%) and ,Stanley' variety (4.26\%).

Conclusion. Analyzing dry substance content as an important parameter, it can be seen that the highest values were obtained by 'Stanley' and 'Vinete de Italia' varieties. Sulfomat product proved itself to be the most suitable for both ecosystems taken into account. Concerning total acidity, the highest values were obtained by 'Tuleu Timpuriu' and 'Tuleu Gras' varieties, together with Sulphur and Sulfomat treatments.

\section{REFERENCES}

1. Dagar A, Asya Weksler, Haya Friedman and Susan Lurie (2012). Gibberellic acid (GA3) application at the end of pit ripening: Effect on ripening and storage of two harvests of 'September Snow' peach, Sci. Hortic., 140, 125-130.

2. Stern RA and Ben-Arie R (2009). GA3 inhibits flowering, reduces hand-thinning, and increases fruit size in peach and nectarine. J. Hort. Sci. Biotechnol. 84, 119-124.

3. Venig Aurora (2006). Practicum de pomicultură generală, Ed. Universității din Oradea.

4. Wertheim SJ (2000). Developments in the chemical thinning of apple and pear, Plant Growth Regul. 31:1-2, 85-100. 